DOI

\title{
АКУПУНКТУРНА ДИНАМІЧНА ЕЛЕКТРОНЕЙРОСТИМУЛЯЦІЯ У КОМПЛЕКСНОМУ ЛІКУВАННІ ХРОНІЧНОГО ПАНКРЕАТИТУ
}

\author{
๑Л. С. Бабінець, Ю. Я. Коцаба, І. М. Галабіцька, Н. В. Марків* \\ ДВНЗ «Тернопільський державний медичний університет імені І. Я. Горбачевського мОз України» \\ *Тернопільська міська комунальна лікарня № 2
}

РЕЗЮМЕ. У статті наведено дані лікування хворих на хронічний панкреатит із включенням до комплексної терапії курсу акупунктурної динамічної електронейростимуляції. Встановили, що запропонований курс лікування сприяв достовірному регресу явищ оксидативного стресу, підвищенню рівня антиоксидантів ферментного та неферментного складу, а також нормалізації показників імунного статусу $(p<0,05)$.

КЛЮчОВІ СЛОВА: хронічний панкреатит, динамічна електронейростимуляція, трофологічні розлади, оксидативний стрес, імунний статус, антиоксиданти, Т-лімфоцитопенія.

Вступ. Використання загальноприйнятого комплексу лікування хворих на хронічний панкреатит (ХП), сформованого згідно із останніми рекомендаціями МОЗ України, реалізує алопатичний підхід до лікування «хвороба - лікуючий фактор". Тривалий, часто пожиттєвий прийом різних медикаментів змушує хворих звертатись до альтернативних методів лікування $[1,4,8]$.

На основі багатовікового досвіду східної медицини, рефлексотерапії і сучасних наукових досліджень був створений унікальний за своєю дією автономний портативний фізіотерапевтичний апарат - ДЕНС (динамічний електронейростимулятор). Динамічна електронейростимуляція - це метод немедикаментозного лікування, заснований на впливі на активні рефлекторні зони і точки динамічними імпульсами електричного струму, форма яких постійно змінюється і залежить від величини електричного опору поверхні шкіри на піделектродній ділянці. При цьому позитивний ефект полягає не тільки у ліквідації болю, але і в дії на причину захворювання [5].

В основу ДЕНС-терапії лягли сучасні уявлення про те, що організм $\epsilon$ складною саморегулюючою системою і при необхідності може сам виробляти необхідні для відновлення біологічно активні речовини $[5,9]$.

Численні дослідження свідчать, що в основі дії динамічної електронейростимуляції лежать багаторівневі рефлекторні і нейрохімічні реакції, що запускають каскад регуляторних і адаптаційних механізмів організму.

Апарати, призначені для ДЕНС-терапії, виробляють слабкі електричні імпульси, які за своїми характеристиками повторюють нервові імпульси людини, тому вони сприймаються організмом як свої власні сигнали, що відновлюють порушені зв'язки між системами регуляції організму і різними органами і тканинами $[5,6,9]$.
Мета роботи: вивчити ефективність дії запропонованої програми корекції на імунний (IC) та прооксидантно-антиоксидантний статуси у хворих на ХП.

Матеріал і методи дослідження. Було обстежено 38 пацієнтів з ХП у фазі стійкої або нестійкої ремісії, віком від 25 до 74 років, 18 чоловіків та 20 жінок. Хворим проводили дослідження імунного та прооксидантно-антиоксидантного статусу. Популяції лімфоцитів визначали за реакцією непрямої імунофлуоресценції, використовуючи панелі моноклональних антитіл до лейкоцитарних антигенів $[1,4]$. Стан оксидативного стресу (OC) оцінювали за рівнем малонового альдегіду (MA), стан антиоксидантних систем захисту (АОСЗ) - за рівнями супероксиддисмутази (СОД), каталази, церулоплазміну, SH-груп, токоферолу, ретинолу (визначали спектрофотометричним методом) та аскорбінової кислоти (визначали за методикою Фармера) [2, 3].

Хворих поділили на дві групи:

1-а (20 чол.) отримувала загальноприйняту схему лікування (ЗСЛ). Вона включала: регулятори моторики органів травлення - спазмолітики (но-шпа 0,04 по 2 таб. 2 р/д) і/або прокінетики (мотиліум 0,01 по 1 таб. 3 р/д), блокатори $\mathrm{H}_{2}$-гістамінових рецепторів (квамател 0,02 ввечері) i/або інгібітори протонної помпи (проксіум 0,04 вранці) і ферменти (креон 25000 по 1 кап. $3 \mathrm{p} /$ д).

2-а група (18 чол.) отримувала додатково до зСЛ 14-денний курс ДЕНС-терапії. Лікування проводили апаратом ДіаДЕНС-ПК, використовуючи виносний точковий терапевтичний електрод. Ним діяли на акупунктурні точки (АТ) в статичному режимі по 3 хв на кожну. Обробляли наступні точки: АТ 96 - проекція підшлункової залози; АТ 55 - точка шень-мень (знеболювальний та седативний ефект); АТ 22 - точка залоз внутрішньої секреції; АТ 39 - точка грудного відділу хребта (знеболю- 
Огляди літератури, оригінальні дослідження, погляд на проблему

вальний та протизапальний ефекти). Точки проекції підшлункової залози на долоні та стопі по системі Су Джок $[5,6,7]$.

Результати й обговорення. Вихідні дані в обох групах були зіставні. У таблиці 1 наведено динаміку показників імунного статусу до та після застосування запропонованих схем лікування.
Аналіз початкових даних показав наявність в обстежуваних хворих на ХП вторинної імунної недостатності за відносним супресорним варіантом, Т-лімфоцитопенії I-ІІ ст. Одночасно у них зменшувалась кількість всіх досліджуваних субпопуляцій лімфоцитів, що свідчило про наявність системного запалення.

Таблиця 1. Динаміка показників імунного статусу під впливом запропонованих методик лікування

\begin{tabular}{|c|c|c|c|c|c|}
\hline \multirow{3}{*}{$\begin{array}{c}\text { Показник } \\
\text { IC }\end{array}$} & \multicolumn{5}{|c|}{ Група порівняння } \\
\hline & \multirow[b]{2}{*}{$\begin{array}{c}\text { група контро- } \\
\text { лю }\end{array}$} & \multicolumn{2}{|c|}{ 1-ша група } & \multicolumn{2}{|c|}{ 2-га група } \\
\hline & & $\begin{array}{l}\text { пацієнти із ХП до } \\
\text { лікування }(n=20)\end{array}$ & $\begin{array}{c}\text { пацієнти із ХП } \\
\text { після лікування } \\
(n=20)\end{array}$ & $\begin{array}{c}\text { пацієнти із ХП до } \\
\text { лікування }(n=18)\end{array}$ & $\begin{array}{c}\text { пацієнти із ХП } \\
\text { після лікування } \\
(\mathrm{n}=18)\end{array}$ \\
\hline CD3, \% & $67,50 \pm 0,59$ & $45,32 \pm 0,75^{*}$ & $47,49 \pm 0,80$ ** & $45,25 \pm 0,84^{*}$ & $\begin{array}{c}60,60 \pm 1,25^{* *} \\
\mathrm{p}_{1}<0,05\end{array}$ \\
\hline CD22, \% & $15,20 \pm 0,18$ & $20,73 \pm 0,34^{*}$ & $21,03 \pm 0,32^{*}$ & $20,85 \pm 0,39 *$ & $\begin{array}{c}18,90 \pm 0,39 * * \\
\mathrm{p}_{1}<0,05\end{array}$ \\
\hline CD16, \% & $13,30 \pm 0,10$ & $10,03 \pm 0,25^{*}$ & $10,89 \pm 0,28 * *$ & $10,05 \pm 0,29 *$ & $\begin{array}{c}12,70 \pm 0,38^{* *} \\
p_{1}<0,05\end{array}$ \\
\hline $\mathrm{CD} 4, \%$ & $40,85 \pm 0,56$ & $31,24 \pm 0,51 *$ & $33,46 \pm 0,51 * *$ & $30,70 \pm 0,64^{*}$ & $\begin{array}{c}40,30 \pm 0,76^{* *} \\
\mathrm{p}_{1}<0,05\end{array}$ \\
\hline $\mathrm{CD} 8, \%$ & $25,55 \pm 0,69$ & $13,73 \pm 0,27$ * & $15,35 \pm 0,33 * *$ & $13,80 \pm 0,31$ * & $\begin{array}{c}19,55 \pm 0,63^{* *} \\
\mathrm{p}_{1}<0,05\end{array}$ \\
\hline $\lg \mathrm{G}$, г/л & $8,72 \pm 0,11$ & $12,31 \pm 0,16 *$ & $11,96 \pm 0,16 * *$ & $12,21 \pm 0,21 *$ & $\begin{array}{c}10,24 \pm 0,23^{* *} \\
\mathrm{p}_{1}<0,05 \\
\end{array}$ \\
\hline $\lg$ А, г/л & $1,74 \pm 0,02$ & $2,82 \pm 0,08^{*}$ & $2,71 \pm 0,08^{* *}$ & $2,96 \pm 0,11$ * & $\begin{array}{c}1,60 \pm 0,05^{* *} \\
\mathrm{p}_{1}<0,05\end{array}$ \\
\hline $\lg$ М, г/л & $1,45 \pm 0,02$ & $2,64 \pm 0,07^{*}$ & $2,44 \pm 0,06^{* *}$ & $2,81 \pm 0,10^{*}$ & $\begin{array}{c}1,52 \pm 0,04^{* *} \\
\mathrm{p}_{1}<0,05\end{array}$ \\
\hline IK & $64,25 \pm 0,64$ & $233,54 \pm 6,40$ * & $192,73 \pm 6,09 * *$ & $231,45 \pm 9,34 *$ & $\begin{array}{c}79,90 \pm 3,99 * * \\
p_{1}<0,05\end{array}$ \\
\hline CH 50 & $289,30 \pm 2,05$ & $160,1351 \pm 2,66^{*}$ & $174,68 \pm 3,03 * *$ & $155,65 \pm 3,85^{*}$ & $\begin{array}{c}257,75 \pm 5,57^{* *} \\
\mathrm{p}_{1}<0,05\end{array}$ \\
\hline IPI & $1,67 \pm 0,03$ & $2,29 \pm 0,04 *$ & $2,20 \pm 0,04^{*}$ & $2,24 \pm 0,07^{*}$ & $\begin{array}{c}2,09 \pm 0,06^{*} \\
p_{1}>0,05\end{array}$ \\
\hline
\end{tabular}

Після проведеного лікування встановили, що у 2-й групі із використанням ДЕНС-терапії показники IC достовірно ( $<<0,05)$ покращилися: рівень зрілих Т-лімфоцитів (CD3) зріс на 33,9\%, Т-хелперів (CD4) - на 31,3\%, Т-супресорів (CD8) - на 41,7\%, В-лімфоцитів (CD22) - на 9,4\%, NK-клітин (CD16) на $26,4 \%$, що було близьким до вікових норм. А у 1-й групі хоча й намітилася позитивна динаміка: рівень Т-лімфоцитів підвищився на 4,8\%, Т-хелперівна 7,1\%, Т-супресорів - на 11,8\%, В-лімфоцитів - на 1,4 \%, NK-клітин - на 8,6 \%, проте вони залишались на рівні Т-лімфоцитопенії I ст.

У таблиці 2 наведено динаміку показників OC-АОСЗ під впливом запропонованих схем корекції. Аналізуючи результати проведених досліджень було встановлено достовірну позитивну динаміку показників ОС-АОСЗ в обох групах пацієнтів після проведеного курсу терапії, проте у пацієнтів, які отримували додатково курс апаратної рефлексотерапії, лікувальний ефект був вагомішим, зменшилися явища ОС за показником МА та достовірно покращився стан АОСЗ як ферментного, так і неферментного складу $(p<0,05)$.

Рівень МА знизився на 10,6 \% у 2-й групі порівняно з 1-ю, рівень СОД підвищився на 12,1\%, каталази - на 8,4 \%, SH-груп - на 11,6 \%, токоферолу - на 3,7 \%, ретинолу - на 25,9 \%, аскорбінової кислоти - на 27,2 \% у 2-й групі порівняно з 1-ю, рівень церулоплазміну знизився на 40,6 \%.

Висновки. 1. У хворих на хронічний панкреатит виявили стан персистуючого оксидативного стресу за рівнем малонового альдегіду, який 
Огляди літератури, оригінальні дослідження, погляд на проблему

Таблиця 2. Динаміка показників ОС-АОСЗ під впливом різних лікувальних програм

\begin{tabular}{|c|c|c|c|c|c|}
\hline \multirow[b]{3}{*}{$\begin{array}{l}\text { Показник } \\
\text { ОС-АОСЗ }\end{array}$} & \multicolumn{5}{|c|}{ Група порівняння } \\
\hline & \multirow[b]{2}{*}{$\begin{array}{c}\text { група кон- } \\
\text { тролю }\end{array}$} & \multicolumn{2}{|c|}{ 1-ша група } & \multicolumn{2}{|c|}{ 2-га група } \\
\hline & & $\begin{array}{c}\text { пацієнти із ХП } \\
\text { до лікування } \\
(n=20)\end{array}$ & $\begin{array}{c}\text { пацієнти } \\
\text { із ХП після } \\
\text { лікування } \\
(\mathrm{n}=20)\end{array}$ & $\begin{array}{c}\text { пацієнти із ХП } \\
\text { до лікування } \\
(n=18)\end{array}$ & $\begin{array}{c}\text { пацієнти } \\
\text { із ХП після } \\
\text { лікування } \\
(\mathrm{n}=18)\end{array}$ \\
\hline МА, ммоль/л & $2,81 \pm 0,09$ & $5,74 \pm 0,02$ & $4,76 \pm 0,19 *$ & $5,79 \pm 0,09$ & $\begin{array}{c}4,26 \pm 0,01 * \\
p_{1}<0,05\end{array}$ \\
\hline Ретинол, мкмоль/л & $1,61 \pm 0,07$ & $0,71 \pm 0,01$ & $0,81 \pm 0,02^{*}$ & $0,68 \pm 0,06$ & $\begin{array}{c}1,02 \pm 0,02^{*} \\
\mathrm{p}_{1}<0,05\end{array}$ \\
\hline Токоферол, мкмоль/л & $113,04 \pm 2,89$ & $63,67 \pm 1,61$ & $73,83 \pm 1,14^{*}$ & $63,71 \pm 2,38$ & $\begin{array}{c}76,57 \pm 0,09 * \\
p_{1}<0,05\end{array}$ \\
\hline Аскорбінова кислота, мг/л & $10,26 \pm 0,25$ & $4,26 \pm 0,09$ & $5,35 \pm 0,07^{*}$ & $4,45 \pm 1,01$ & $\begin{array}{c}6,81 \pm 0,25^{*} \\
p_{1}<0,05\end{array}$ \\
\hline СОД, ум, од, & $62,15 \pm 0,33$ & $45,58 \pm 1,91$ & $53,22 \pm 1,69 *$ & $46,31 \pm 4,07$ & $\begin{array}{c}59,66 \pm 2,62^{*} \\
\mathrm{p}_{1}<0,05\end{array}$ \\
\hline Каталаза, \% & $17,48 \pm 0,21$ & $13,95 \pm 0,08$ & $14,79 \pm 0,11 *$ & $13,96 \pm 0,45$ & $\begin{array}{c}16,03 \pm 0,51 * \\
\mathrm{p}_{1}<0,05\end{array}$ \\
\hline SH-групи, ммоль/л & $68,51 \pm 1,46$ & $45,09 \pm 2,01$ & $50,83 \pm 1,02 *$ & $45,39 \pm 2,62$ & $\begin{array}{c}56,71 \pm 2,28^{*} \\
\mathrm{p}_{1}<0,05\end{array}$ \\
\hline Церулоплазмін, мг/л & $245,6 \pm 7,6$ & $445,11 \pm 6,92$ & $383,61 \pm 8,71^{*}$ & $439,84 \pm 21,61$ & $\begin{array}{c}359,22 \pm 6,31 * \\
\mathrm{p}_{1}<0,05\end{array}$ \\
\hline $\begin{array}{l}\text { Примітки: } 1 .{ }^{*} \text { - достовірність } \\
\text { 2. ** - достовірність даних до } \\
\text { 3. } \text { p }_{1} \text { достовірність даних мі }\end{array}$ & відносно & $\begin{array}{l}\text { контролю }(p<c \\
\text { ої̆ групі }(p<0,0\end{array}$ & & & \\
\hline
\end{tabular}

перебігав на тлі зниженого рівня антиоксидантів ферментного та неферментного складу, а також наявність у них вторинної імунної недостатності за відносним супресорним варіантом, Т-лімфоцитопенію І-ІІ ст.

2. Встановили, що використання у комплексному лікуванні хворих на хронічний панкреатит 14-денного курсу ДЕНС-терапії за запропонованою схемою сприяло достовірному регресу явищ оксидативного стресу, підвищенню рівня антиоксидантів ферментного та неферментного складу, а також нормалізації показників імунного статусу $(p<0,05)$.

\section{ЛІТЕРАТУРА}

1. Бабінець Л. С. Переваги поєднаного використання рефлексотерапії та гомеопатії в комплексному лікуванні хворих на хронічний панкреатит / Л. С. Бабінець // Архів клін. мед. - 2005. - № 2 (8). - С. 42-44.

2. Бабінець Л. С. Дисбіоз товстої кишки як чинник порушень в антиоксидантному статусі хворих на хронічний панкреатит у поєднанні із хронічним захворюванням легень, шляхи оптимізації лікування / Л. С. Бабінець, О. С. Квасніцька // Вісник наукових досліджень. - 2011. № 4. - С. 44-48.

3. Бабінець Л. С. Роль про- та антиоксидантного статусу і тютюнопаління у формуванні трофологічних розладів при хронічному панкреатиті в поєднанні з ХОЗЛ / Л. С. Бабінець, О. С. Квасніцька // Вестник Клуба Панкреатологов. - 2012. - № 4. - С. 6-7.

4. Новые возможности реабилитации больных хроническим рецидивирующим панкреатитом / Н. Б. Губергриц, В. Я. Колкина // Биол. медицина. - 2003. № 1. - С. 19-24.
5. ДиаДЭНС. Руководство подинамической электронейростимуляции аппаратами ДиаДЭНС-Т и ДиаДЭНСДТ; под ред. д. мед. н. В. В. Чернышева. - Екатеринбург : ООО «РЦ АРТ», 2005. - 283 С.

6. ДиаДЭНС-ПК лечебно-диагностический комплекс : руководство по эксплуатации. - Екатеринбург : ООО «РЦ АРТ», 2010. - 84 с.

7. Здыбский В. И. Лабиринты рефлексотерапии (150 вопросов начинающим свой путь) : монография / В. И. Здыбский. - Изд. 2-е, перер. и доп. - Харьков : СПДФЛ Мосякин В.Н., 2005. - 316 с.

8. Калинин А. В. Хронический панкреатит: распространенность, этиология, патогенез, классификация и клиническая характеристика этиологических форм (сообщение первое) / А. В. Калинин // Клин. перспективы гастроэнтерол., гепатол. - 2006. - № 6. - С. 5-15.

9. Универсальный регистр ДЭНС-терапии / В. В. Чернышев, В. В. Малахов, А. Ю. Рявкин, С. Ю. Рявкин. - Екатеринбург, 2003. - 165 с. 
Огляди літератури, оригінальні дослідження, погляд на проблему

ACUPUNCTURE DYNAMIC ELECTRONEUROSTIMULATION IN COMPLEX THERAPY OF CHRONIC PANCREATITIS

@L. S. Babinets, Yu. Ya. Kotsaba, I. M. Halabitska, N. V. Markiv*

SHEI «Ternopil State Medical University by I. Ya. Horbachevsky of MPH of Ukraine»

Ternopil City Municipal Hospital № 2*

SUMMARY. In the treatment of patients with chronic pancreatitis the use of machine reflexology course, which includes 12-14 sessions of DENS according to the proposed scheme, contributes to a significant regression of the effects of oxidative stress, and also to the increase in the level of antioxidant enzyme and no enzyme composition and the normalization of the indices of immune status $(p<0.05)$.

KEY WORDS: chronic pancreatitis, dynamic electroneurostimulation, trophological disorders, oxidative stress, immune status, antioxidants, T-lymphopenia.

Отримано 06.10.2015 